\title{
Comparing qPCR and Nested PCR Diagnostic Methods for Aster Yellows Phytoplasma in Aster Leafhoppers
}

\author{
Katherine L. Demeuse, Ari S. Grode, and Zsofia Szendrei, Department of Entomology, Michigan State University, East Lansing 48824
}

\begin{abstract}
Katherine L. Demeuse, Ari S. Grode, and Zsofia Szendrei. 2016. Comparing qPCR and nested PCR diagnostic methods for aster yellows phytoplasma in aster leafhoppers. Plant Dis. 100:2513-2519.

The aster yellows phytoplasma (AYp) is a wall-less bacterium that causes damage in multiple crops. They are spread primarily by the aster leafhopper, Macrosteles quadrilineatus (Hemiptera: Cicadellidae). A total of 3,156 aster leafhoppers were collected during the 2014 and 2015 growing seasons in Michigan celery and carrot fields using sweep nets. The objective of this study was to test previously developed $16 \mathrm{~S}$ rDNA phytoplasma gene primers to find the most reliable and least time-consuming method for AYp detection in leafhoppers. Nested polymerase chain reaction (PCR) was performed with universal primers P1/P7 and R16F2n/R16R2, and then, restriction enzymes AluI, MseI, and HhaI identified the phytoplasma

to subgroup. Over the two years, $2.2 \%$ of samples were phytoplasma positive with nested PCR, classified in subgroups 16SrI-A or 16SrI-B. Al samples were also tested with a TaqMan quantitative qPCR assay with universal phytoplasma primers and probe and $4.6 \%$ tested positive. A subset of samples were also tested with AYp-specific SYBR green qPCR, showing a $>93 \%$ similarity between SYBR green and TaqMan qPCR assay results. The qPCR assays were more than two times faster than nested PCR. However, qPCR assays likely have specificity issues that need to be addressed before they can be used as a reliable method of detection for AYp in leafhoppers.
\end{abstract}

Phytoplasmas are cell wall-less bacteria that are transmitted by phloem-feeding insects, causing more than 700 diseases in hundreds of plant species (Weintraub and Beanland 2006). They are difficult to study, since, unlike many other plant disease-causing organisms, they cannot be cultured in the laboratory (Lee et al. 2000). Detection of the organism in vivo is challenging because it is usually present in low concentrations in both plant and insect tissue (Weintraub and Beanland 2006). Methods to detect phytoplasmas, such as microscopy and serological techniques, were replaced by polymerase chain reaction (PCR) assays in the 1990s (Nejat and Vadamalai 2013). In particular, nested PCR has been widely adopted for detecting different phytoplasmas (Gundersen and Lee 1996). Typically, this involves two amplifications of PCR using universal phytoplasma primers, followed by restriction fragment length polymorphism (RFLP) analysis that provides definitive phytoplasma identification at the subgroup level (Lee et al. 1993; Schneider et al. 1993). The nested PCR method is necessary due to its increased specificity and because a single PCR reaction is unable to detect low amounts of phytoplasma (Nejat and Vadamalai 2013). The disadvantages of nested PCR is that it is time consuming, it can generate bands of different intensity that are difficult to interpret, and it can generate bands at unexpected sizes (Franova 2011; Harrison et al. 2002). As a result, researchers have developed quantitative qPCR assays to more efficiently detect phytoplasma in plants and insects with increased sensitivity and specificity (Frost et al. 2011; Hren et al. 2007; Jawhari et al. 2015). Among the advantages of $q P C R$ is that each sample can be processed in a single reaction vessel and it does not require the reaction products to be analyzed with gel electrophoresis. Several qPCR methods have been developed for phytoplasma detection, such as SYBR green (Hollingsworth et al. 2008; Torres et al. 2005) and TaqMan (Christensen et al. 2004; Crosslin et al. 2006; Galetto and

Corresponding author: Zsofia Szendrei, E-mail: szendrei@msu.edu

*The $\boldsymbol{e}$-Xtra logo stands for "electronic extra" and indicates that one supplementary figure and one supplementary table are published online.

Accepted for publication 24 July 2016.

http://dx.doi.org/10.1094/PDIS-12-15-1444-RE

(C) 2016 The American Phytopathological Society
Marzachi 2009; Jawhari et al. 2015) that have generally been suggested as high-throughput diagnostic tools.

Aster yellows phytoplasma (AYp,16SrI) is one of the largest and most diverse groups of phytoplasma (Lee et al. 2000). AYp infection in susceptible and economically important plants, such as carrots, celery, lettuce, and multiple ornamental flower varieties, can affect both crop yield and value (Chapman 1973). Although AYp is transmitted by at least 24 different leafhopper species (Christensen et al. 2005; Lee et al. 2003), the polyphagous aster leafhopper (Macrosteles quadrilineatus, Hemiptera: Cicadellidae) is considered to be the main vector in North America, due to its abundance in agricultural crops (Hoy et al. 1992). To date, plant breeding and vector management have been proposed as the two most successful avenues for phytoplasma management in crops (Weintraub and Beanland 2006). Preventing AYp from entering the plant tissue is the main strategy to control phytoplasma infection in commercial agriculture, most commonly by controlling the leafhopper population with insecticide applications (Frost et al. 2013; Weintraub and Beanland 2006).

The presence of AYp in field-collected leafhoppers precedes the appearance of the disease in plants in the field, due to a 2- to 3-weeklong vector latency period along with a 21- to 30-day incubation period of the phytoplasma in the host plant (Delahaut 1997; Frost et al. 2011). Therefore, testing for phytoplasma presence in leafhoppers may allow pest managers to reduce infected leafhopper populations that pose a risk for their crops. In addition, the presence of AYp in the leafhopper is a better predictor of plant disease incidence in the field than leafhopper numbers alone, because it shows the number of leafhoppers that may be infectious and be able to transmit AYp to field crops (Goodwin et al. 1999; Wally et al. 2004). Traditionally, the only way to detect AYp in field-collected leafhoppers is through indicator plants in a greenhouse bioassay (Mahr et al. 1993), but this method is time consuming and labor intensive. A quick and accurate AYp detection method from leafhoppers would allow growers to apply insecticides as a function of the presence of phytoplasma and abundance of leafhoppers in a field (Hoy et al. 1992). Overall, this may improve the effectiveness of insecticide applications along with preventing unnecessary applications, which will benefit the environment, increase crop health, and increase crop yield.

However, diagnostic methods for AYp in field-collected leafhoppers on a large scale are relatively unexplored. Comparison of PCR methods for AYp detection, using over 1,000 field-collected leafhoppers, determined that a single PCR reaction yielded false negatives (Wally 
et al. 2004). The significant time investment to perform nested PCR is in contrast with the practical needs of pest managers that require a maximum 24-h sample turnaround time from leafhopper collection. One of the earliest reports on qPCR testing of AYp from fieldcollected aster leafhoppers tried to compare a nonquantitative and a qPCR method, but the results of the two methods were not comparable (Goodwin et al. 1999).

The goal of this study was to compare already developed diagnostic assays for AYp detection in field-collected aster leafhoppers. We compared two techniques, nested PCR followed by RFLP analysis (Gundersen and Lee 1996; Lee et al. 1993) and a TaqMan qPCR assay (Christensen et al. 2004). A subsample was also run with an AYp-specific SYBR green qPCR assay (Hollingsworth et al. 2008). Sensitivity and the time it took to process the samples with each assay were compared, using aster leafhoppers collected in celery and carrot fields across Michigan in 2014 and 2015.

\section{Materials and Methods}

Leafhopper collections. Aster leafhoppers were collected from 20 commercial celery and carrot farms across 12 counties in Michigan during the 2014 and 2015 growing seasons. In 2014, leafhoppers were collected from mid-May through the end of July. In 2015, leafhoppers were collected from mid-May through the first week of August. Samples were collected using sweep nets, with a minimum of 100 sweeps per field per collection day and a minimum of 30 leafhoppers per field. Leafhoppers were transported in a cooler to the lab and were stored at $-20^{\circ} \mathrm{C}$, until they were identified and were placed into homogenization tubes.

DNA extractions. One to three leafhoppers from a given field and collection date were placed into a 2-ml homogenization tube (Sarstedt, Nümbrecht, Germany), with $70 \mu l$ of high salt extraction buffer (Aljanabi and Martinez 1997) and three homogenization beads (2.3 mm diameter, zirconia/silica; BioSpec Products, Inc., Bartlesville, OK). Leafhoppers were homogenized for $60 \mathrm{~s}$ (FastPrep-24, MP Biomedicals, Santa Ana, CA). DNeasy total DNA isolation kit (Qiagen, Valencia, CA) was used to extract DNA, according to the manufacturer's instructions. Samples with one or two leafhoppers were suspended in $100 \mu$ l elution buffer, while samples with three leafhoppers were suspended in $200 \mu$ l elution buffer.

Nested PCR and RFLP. All leafhopper samples were tested using nested PCR and RFLP to identify phytoplasma to subgroup. The universal phytoplasma primers P1 and P7 (Schneider et al. 1995) were used in the first amplification, followed by universal phytoplasma primers R16F2n and R16R2 (Gundersen and Lee 1996) in the second amplification (Supplementary Table 1). The first round of amplification consisted of $2 \mu$ l of leafhopper DNA of varied concentrations within a range of 6 to $30 \mathrm{ng} / \mu \mathrm{l}, 1 \times \mathrm{PCR}$ buffer (Invitrogen, Grand Island, NY), $1.56 \mathrm{mM} \mathrm{MgCl} 2$ (50 mM, Invitrogen), $0.21 \mathrm{mM}$ dNTPs (10 mM; Promega, Madison, WI), $0.2 \mu \mathrm{M}$ of each primer (Thermo Fisher Scientific, Waltham, MA), $41.67 \mathrm{mM}$ bovine serum albumin (10 mg/ml; New England Biolabs, Ipswich, MA), $0.31 \mathrm{U}$ Taq polymerase ( $5 \mathrm{U} / \mu \mathrm{l}$; Invitrogen), and nuclease-free water for a total volume of $12 \mu$. The reactions were denatured at $95^{\circ} \mathrm{C}$ for $5 \mathrm{~min}$, followed by 35 cycles of $95^{\circ} \mathrm{C}$ for $1 \mathrm{~min}, 53^{\circ} \mathrm{C}$ for $1 \mathrm{~min}$, and $72^{\circ} \mathrm{C}$ for $2 \mathrm{~min}$, with a final extension of $72^{\circ} \mathrm{C}$ for $10 \mathrm{~min}$ in a Mastercycler Pro thermocycler (Eppendorf, Hamburg, Germany). The PCR product was diluted with water 1:30, and $1 \mu$ l of the diluted product was used as the DNA template for the second round of amplification, with the same amount of PCR components as above. The second reaction was denatured at $94^{\circ} \mathrm{C}$ for $10 \mathrm{~min}$, followed by 38 cycles of $94^{\circ} \mathrm{C}$ for $1 \mathrm{~min}, 55^{\circ} \mathrm{C}$ for $2 \mathrm{~min}$, and $72^{\circ} \mathrm{C}$ for $3 \mathrm{~min}$, followed by a final extension of $72^{\circ} \mathrm{C}$ for $10 \mathrm{~min}$. The PCR products were run on a $1 \%$ agarose gel precast with GelRed (Biotium, Hayward, CA) and was visualized with a PhotoDoc-It UV light transilluminator (UVP, Upland, CA). RFLP analyses were then performed with all samples that gave a band at the expected size (1,200 bp), which allowed the AYp subgroup to be identified. The nested PCR products $(6 \mu \mathrm{l})$ were digested individually with restriction enzymes HhaI, MseI, and AluI (New England Biolabs), according to the manufacturer's instructions. Restriction products were run on a $2 \%$ agarose gel precast with GelRed for $2 \mathrm{~h}$ at $90 \mathrm{~V}$. Bands were visualized with a UV light transilluminator and were compared with published RFLP profiles (Lee et al. 1998; Wei et al. 2007). To see if reprocessing can be done with nested PCR, all samples that gave bands at the expected size were run with nested PCR a second time.

qPCR assays. The presence of AYp was tested with a TaqMan assay using universal phytoplasma primers and probe (Thermo Fisher Scientific) (Christensen et al. 2004). Reactions consisted of $1 \times$ TaqMan master mix (Life Technologies, Grand Island, NY), $300 \mu \mathrm{M}$ forward and reverse primers, $200 \mu \mathrm{M}$ TaqMan probe, $2 \mu \mathrm{l}$ DNA template, and nuclease-free water for a final volume of $10 \mu \mathrm{l}$. Reactions were held at $50^{\circ} \mathrm{C}$ for $2 \mathrm{~min}$ and $95^{\circ} \mathrm{C}$ for $10 \mathrm{~min}$, followed by $40 \mathrm{cy}-$ cles of $95^{\circ} \mathrm{C}$ for $15 \mathrm{~s}$ and $60^{\circ} \mathrm{C}$ for $1 \mathrm{~min}$ in a StepOnePlus qPCR machine (Applied Biosystems, Foster City, CA). A small subsample (13 samples) of the qPCR products were run on a 1\% agarose gel and were compared with a GeneRuler low-range DNA ladder (Thermo Fisher Scientific). In addition, 100 positive samples were run a second time to see if results could be replicated.

A subset of samples were run with SYBR green master mix and a set of primers specific to the AYp group (Hollingsworth et al. 2008). All samples positive with TaqMan qPCR were tested with SYBR green qPCR. In addition, 10 samples randomly taken from each cycle threshold $(\mathrm{Ct})$ range above 30 (e.g., $\mathrm{Ct}$ 30-31, 31-32, 33-34), obtained with TaqMan qPCR were also tested with SYBR green qPCR. Reactions consisted of $1 \times$ Power SYBR green (Life Technologies), $50 \mathrm{nM}$ of each primer, and nuclease-free water for a final volume of $20 \mu \mathrm{l}$. Reactions were held at $95^{\circ} \mathrm{C}$ for $10 \mathrm{~min}$, followed by 40 cycles of $95^{\circ} \mathrm{C}$ for $15 \mathrm{~s}$ and $60^{\circ} \mathrm{C}$ for $1 \mathrm{~min}$, and a melting curve was performed in a StepOnePlus qPCR machine. For both qPCR methods, each sample was replicated twice. In addition, a small subset (13 samples) of the $\mathrm{qPCR}$ products was run on a $1 \%$ agarose gel. In addition, to determine if the leafhopper DNA contained any inhibitors that would affect PCR, 11 randomly selected samples were run with leafhopper (cp6) primers developed by Frost et al. (2011). Reactions consisted of $1 \times$ Power SYBR green, $0.2 \mu \mathrm{M}$ of the forward and reverse primer, $8.4 \mu \mathrm{l}$ leafhopper DNA at varying concentrations, and nuclease-free water for a final volume of $20 \mu \mathrm{l}$. Reactions were held at $95^{\circ} \mathrm{C}$ for $10 \mathrm{~min}$, followed by 40 cycles of $95^{\circ} \mathrm{C}$ for $30 \mathrm{~s}$ and $60^{\circ} \mathrm{C}$ for $30 \mathrm{~s}$, and a melting curve was performed in a StepOnePlus qPCR machine.

Assay sensitivity. To compare the sensitivities of the three assays, a dilution series $\left(10^{-1}\right.$ to $\left.10^{-7}\right)$ was created using a sample that was a known positive for phytoplasma 16 SrI-B, verified by RFLP analyses. The sample was also verified by Sanger sequencing performed at the Research Technology Support Facility's Genomics Core at Michigan State University. The nested PCR product of the sample was purified using QIAquick PCR purification kit (Qiagen) and was sequenced. The total double-stranded (ds)DNA concentration was then measured with a Qubit fluorometer (Invitrogen). Three replicates of each dilution were tested and standard error of the triplicates was calculated using TaqMan and SYBR green qPCR assays.

qPCR product cloning. To develop calibration curves of our AYp and phytoplasma gene targets, PCR products of a positive field sample were generated using both TaqMan and SYBR green qPCR methods. Products were purified using the QIAquick PCR purification kit (Qiagen) and were cloned into the pGEM-T Easy plasmid (Promega, Madison, WI), according to the manufacturer's instructions. Escherichia coli JM109 were transformed with the plasmid constructs containing target sequences. Transformants were selected using blue-white selection and were purified from overnight cultures of E. coli trasformants using a QIAprep Spin miniprep kit (Qiagen). The region of the pGEM-T Easy plasmid containing targets was sequenced at the Research Technology Support Facility's Genomics Core at Michigan State University. Sequences were compared with the National Center for Biotechnology Information database using BLAST.

Purified plasmids were quantified using the Qubit dsDNA BR assay kit (Thermo Fisher Scientific). DNA concentrations (expressed as plasmid copy number/microliter) were calculated as follows, assuming the average weight of a nucleotide base pair was $660 \mathrm{Da}$ : DNA $($ copies $/ \mu \mathrm{l})=$ DNA $(\mathrm{ng} / \mu \mathrm{l}) /\left[\left(\mathrm{DNA}(\mathrm{bp}) \times\left(1 \times 10^{9}\right)(\mathrm{ng} / \mathrm{g}) \times\right.\right.$ $\left.660(\mathrm{Da} / \mathrm{bp})) / 6.022 \times 10^{23}(\mathrm{copies} / \mathrm{mol})\right]$. 
A 10-fold dilution series was prepared for each gene target, based on plasmid copy number per microliter, prepared in concentrations ranging from $10^{10}$ to 1 copy per microliter. There are two copies of the $16 \mathrm{~S}$ rDNA gene in the phytoplasma genome, so the phytoplasma copy number would be half the number of plasmid copies (Schneider and Seemuller 1994). The analytical sensitivity of our primers was evaluated using the full dilution series and primer efficiency (E), based on standards ranging from $10^{7}$ to 1 copy per microliter, and was calculated as: $\mathrm{E}=10^{-1 / \text { slope of dilution curve }}$.

To evaluate variability within a sample, each dilution was replicated three times and was run on a single sample plate, for each assay.

Assay comparison. The time required for processing 96 samples for all three methodologies was compared, including DNA extraction, setting up PCR reactions, time in the thermocyclers, and time manipulating samples after PCR. qPCR assays were evaluated by producing serial dilutions of the plasmid containing a fragment of the $16 \mathrm{~S}$ gene of AYp described previously and spiking plasmid into either nucleasefree water or leafhopper phytoplasma-negative DNA. The different concentrations of plasmid DNA was mixed 1:1 for the Taqman assay and 1:3 for the SYBR green assay, so as to obtain the same plasmid copy number with both assays, with $35 \mathrm{ng}$ of total DNA extracted from leafhoppers in colonies kept at Michigan State University greenhouses. This was used as DNA template, with the same qPCR conditions and components as previously described for both qPCR assays. Results were compared with the same amount of plasmid DNA mixed with nuclease-free water. For diagnostic purposes, a Ct cutoff value was determined for both qPCR assays. This was done by observing the variation of the $\mathrm{Ct}$ values of the triplicate replicates in the dilution series (Bohuski et al. 2015). After establishing the Ct cutoff value, the number of positive samples for each assay was also compared.

Statistical analyses. Pearson product-moment correlation coefficients were computed to determine the relationship between TaqMan qPCR and nested PCR in the number of positive samples, categorized into $\mathrm{Ct}$ ranges obtained with TaqMan qPCR (R, version 3.2.2). A correlation coefficient was calculated that included all samples (Ct range of 20 to 39). Correlation coefficients were also calculated in the $\mathrm{Ct}$ range of 20 to 30 along with the range of 31 to 39 . In addition, a Pearson product-moment correlation coefficient was computed to show the relationship between the $\mathrm{Ct}$ values using TaqMan $\mathrm{qPCR}$ versus the SYBR green qPCR assay. The number of positive samples over the two years as determined with nested and TaqMan qPCR was compared with a $t$ test $(\alpha=0.05)$. Prevalence of phytoplasma throughout the 2014 and 2015 growing seasons was calculated for both nested PCR and TaqMan qPCR. Prevalence was determined as the proportion of positive samples out of all samples collected on a single day in a single field. A linear regression was performed to determine the relationship between phytoplasma prevalence and time for both types of assays for the 2014 and 2015 growing seasons.

\section{Results}

A total of 894 and 2,262 leafhoppers were processed during the 2014 and 2015 growing seasons, respectively. Of the 3,156 leafhoppers, $82.2 \%$ were collected from celery fields. The leafhoppers were combined to create 585 and 974 samples in 2014 and 2015, respectively. All samples were tested with nested PCR and TaqMan qPCR, 37 samples were processed with RFLP and 185 with SYBR green qPCR.
Nested PCR and RFLP. In 2014 and 2015, 4.8 and 3.1\%, respectively, of the leafhopper samples tested positive with nested PCR (Table 1), resulting in 58 positive samples over the two years. Of the total number of samples, $11 \%(171$ of 1,559$)$ yielded faint bands at unexpected sizes, that varied greatly in length. These samples were considered to be phytoplasma-negative. Positive results could not be replicated a second time for $36.2 \%$ (21 of 58) of the nested PCR

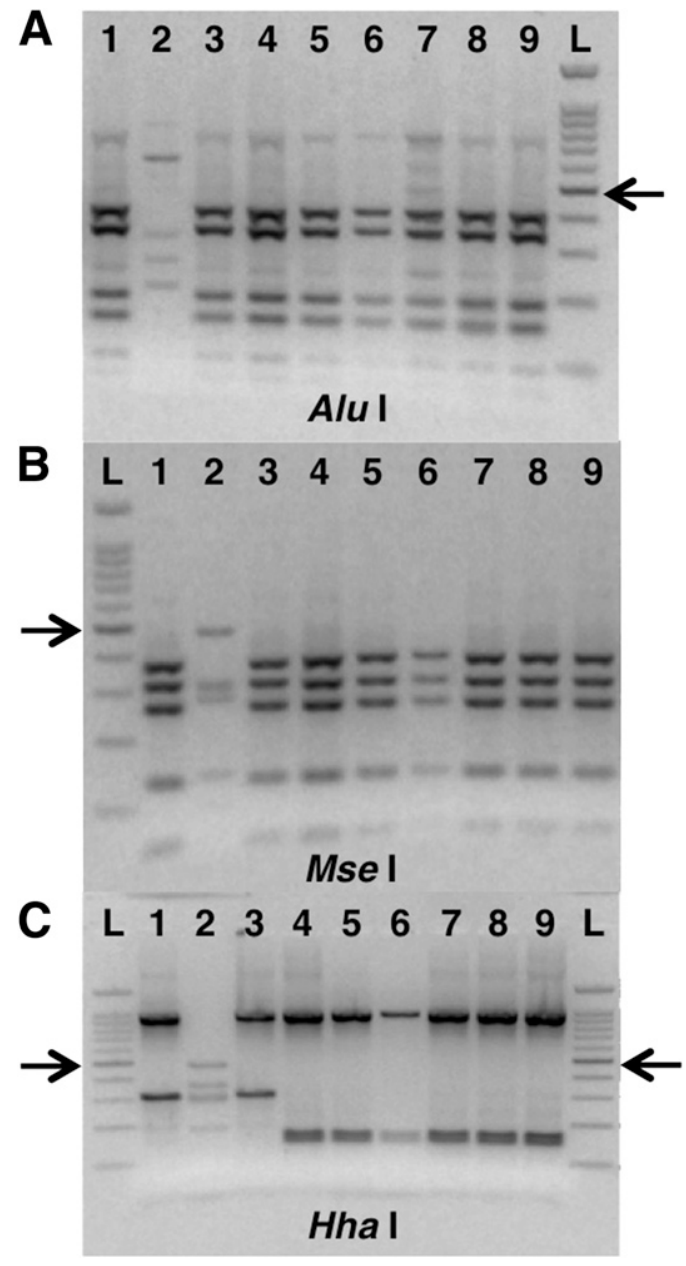

Fig. 1. Restriction fragment length polymorphism (RFLP) using three restriction enzymes with a subset of nine samples that produced bands at the expected size with nested polymerase chain reaction (PCR) $(1,200 \mathrm{bp})$. PCR products from the second amplification of nested PCR using R16F2n/R16R2 primers were digested individually by restriction enzymes Alul, Msel, and Hhal. Samples 1, 3 to 5, and 7 to 9 were positive with quantitative PCR. Well L contains a 100-bp ladder, and the arrows indicate the location of a 500-bp product. For all three RFLP profiles, sample 2 did not match any published phytoplasma profiles and, therefore, was considered false positive. A, PCR products digested with restriction enzyme Alul. Samples 1 and 3 to 9 are in the $16 \mathrm{Srl}$ group. B, PCR products digested with restriction enzyme Msel. Samples 1 and 3 to 9 are in the 16Srl group. C, PCR products digested with restriction enzyme Hhal. Samples 1 and 3 are in the 16Srl-A subgroup, and samples 4 to 9 are in the $16 \mathrm{Srl}-\mathrm{B}$ subgroup.

Table 1. Results using two polymerase chain reaction (PCR) assays for two consecutive growing seasons to detect aster yellows phytoplasma in aster leafhoppers

\begin{tabular}{|c|c|c|c|c|c|}
\hline \multirow[b]{2}{*}{ Growing season } & \multirow[b]{2}{*}{ Assay } & \multirow[b]{2}{*}{ Positives } & \multirow[b]{2}{*}{ True positives ${ }^{a}$} & \multicolumn{2}{|c|}{ RFLP analysis } \\
\hline & & & & 16SrI-A & 16SrI-B \\
\hline \multirow[t]{2}{*}{2014} & Nested PCR & $4.8 \%(28 / 585)$ & $32.1 \%(9 / 28)^{\mathrm{a}}$ & $0 \%(0 / 9)$ & $100 \%(9 / 9)$ \\
\hline & Taqman qPCR & $8.2 \%(48 / 585)^{\mathrm{b}}$ & & & \\
\hline \multirow[t]{2}{*}{2015} & Nested PCR & $3.1 \%(30 / 974)$ & $85.7 \%(24 / 30)^{\mathrm{a}}$ & $29.2 \%(7 / 24)$ & $70.8 \%(17 / 24)$ \\
\hline & Taqman qPCR & $2.4 \%(23 / 974)^{\mathrm{b}}$ & & & \\
\hline
\end{tabular}

\footnotetext{
a True positives with nested PCR were considered to be samples that produced bands at the appropriate size after retesting, and that matched published phytoplasma restriction fragment length polymorphism (RFLP) patterns.

b Positives with TaqMan qPCR were considered to be samples with a cycle threshold of less than 31 .
} 
positives; these samples had faint bands at the expected size (1,200 bp) and were, thus, considered phytoplasma-negative. Of the 37 remaining samples, 33 (2.2\% of the total samples) matched published RFLP profiles for phytoplasma and were classified in either the phytoplasma group $16 \mathrm{SrI}-\mathrm{A}$ or $16 \mathrm{SrI}-\mathrm{B}$, with the majority of samples belonging to the latter group (Table 1; Fig. 1C). According to the RFLP analyses, $10.8 \%$ (4 of 37) did not match published profiles for phytoplasmas and were considered false positives (Fig. 1).

qPCR assays. The PCR products run on an agarose gel using TaqMan and SYBR green qPCR assays all gave bands at the expected sizes of 65 and 95 bp, respectively (Supplementary Fig. S1). Of the 100 positive samples that were reprocessed with the TaqMan qPCR assay, $82 \%$ of the samples had a higher average $\mathrm{Ct}$ value the second time, which suggests there may have been some DNA degradation due to sample thawing and freezing.

There was no PCR inhibition when AYp-negative leafhopper DNA was spiked with phytoplasma plasmid DNA (Table 2). In addition, 10 of the 11 samples run with the cp6 leafhopper DNA primers had a Ct value of 28 or less. Therefore, there were likely no major inhibitors in the leafhopper DNA affecting qPCR.

qPCR product cloning. The most similar GenBank sequence result to the SYBR green product was AYp (accession L33767), a $100 \%$ match. There were 101 phytoplasma sequence matches (100\%) to the TaqMan product. The efficiency for TaqMan primers was $103.5 \%$ and for SYBR green primers $90.3 \%$. Standard curves were made for both qPCR assays (Fig. 2).

Assay sensitivity. The sample used to make a dilution series to compare the sensitivities of all three qPCR assays matched $100 \%$ with phytoplasma $16 \mathrm{~S}$ rDNA in the GenBank database, including AYp, and had a total dsDNA concentration of $30.8 \mathrm{ng} / \mu \mathrm{l}$. For the TaqMan and SYBR green qPCR assays, amplification occurred in all three of the replicates at a sample dilution up to the $10^{-5}$ for TaqMan qPCR and $10^{-6}$ for SYBR green qPCR (Fig. 3). However, after the $10^{-4}$ dilution, the variation among the three replicates for both of the qPCR assays increased 17-fold. Nested PCR was less sensitive than qPCR, showing no amplification after the $10^{-4}$ dilution (Fig. 3C).

Assay comparison. On average, it took 2.5 and 2.3 times longer to process 96 samples using nested PCR than the TaqMan qPCR and SYBR green qPCR assay, respectively (Table 3). A Ct cutoff value was established for both qPCR assays for diagnostic purposes. For

Table 2. Serial dilutions of a plasmid containing a fragment of the $16 \mathrm{~S}$ gene of AYp for SYBR green and TaqMan quantitative polymerase chain reaction (qPCR) assays. Plasmids are combined with nuclease-free water or leafhopper phytoplasma negative DNA

\begin{tabular}{lccc}
\hline & & \multicolumn{2}{c}{ Cycle threshold value } \\
\cline { 3 - 4 } Assay & $\begin{array}{c}\text { Plasmid copy } \\
\text { number }\end{array}$ & In water & $\begin{array}{c}\text { In leafhopper } \\
\text { DNA solution }\end{array}$ \\
\hline TaqMan & 1 & $34.80 \pm 1.29$ & $33.80 \pm 0.20$ \\
& 10 & $31.52 \pm 0.18$ & $31.30 \pm 0.32$ \\
& $10^{2}$ & $27.80 \pm 0.08$ & $27.69 \pm 0.18$ \\
& $10^{3}$ & $25.16 \pm 0.23$ & $25.07 \pm 0.21$ \\
& $10^{4}$ & $21.04 \pm 0.25$ & $20.89 \pm 0.18$ \\
& $10^{5}$ & $17.92 \pm 0.28$ & $17.77 \pm 0.14$ \\
SYBR green & $10^{6}$ & $14.65 \pm 0.02$ & $14.82 \pm 0.20$ \\
& $10^{7}$ & $10.96 \pm 0.11$ & $11.24 \pm 0.07$ \\
1 & $\mathrm{ND}$ & $35.84 \pm 1.05$ \\
& 10 & $34.98 \pm 0.52$ & $33.51 \pm 0.81$ \\
& $10^{2}$ & $34.21 \pm 0.36$ & $33.41 \pm 0.15$ \\
& $10^{3}$ & $26.97 \pm 0.25$ & $27.07 \pm 0.35$ \\
$10^{4}$ & $23.79 \pm 0.19$ & $24.16 \pm 0.33$ \\
& $10^{5}$ & $20.17 \pm 0.22$ & $20.01 \pm 0.22$ \\
$10^{6}$ & $16.41 \pm 0.14$ & $16.50 \pm 0.20$ \\
& $10^{7}$ & $10.38 \pm 0.18$ & $10.54 \pm 0.13$ \\
\hline
\end{tabular}

${ }^{a}$ ND indicates there was no amplification after 40 cycles. For TaqMan qPCR, linear regression analysis showed a slope of $-3.39\left(R^{2}=0.99\right)$ for water and $-3.26\left(R^{2}=0.99\right)$ for DNA solution. For SYBR green qPCR, linear regression analysis showed a slope of -4.11 for water $\left(R^{2}=0.99\right)$ and $-3.63\left(R^{2}=\right.$ 0.97) for DNA solution. the TaqMan assay, one plasmid copy gave average $\mathrm{Ct}$ values of $34.8 \pm 1.29$ with water and $33.80 \pm 0.20$ with leafhopper DNA, as shown in Table 2 . There was also high variation in the three replicates at four copies of plasmid in the standard curve, at an average $\mathrm{Ct}$ value of 32.5 (Fig. 2A). Therefore, it was determined that a suitable cutoff was a $\mathrm{Ct}$ value of 31 for the TaqMan qPCR assay for diagnostic purposes. For SYBR green, the standard curve showed that eight copies of phytoplasma plasmid DNA yielded an average Ct value of approximately 32.7 , where the variation between the replicates was much larger than the less-diluted samples. Therefore, a $\mathrm{Ct}$ value of 32 was chosen to be the cutoff value for the SYBR green assay in this paper. The majority of samples $(75.8 \%)$ positive with nested PCR were also positive with TaqMan qPCR. However, $0.5 \%$ (8 of 1,559) of the samples were positive with nested PCR but negative with TaqMan qPCR and $64.7 \%$ of samples positive with TaqMan qPCR were negative with nested PCR. There were significantly more positive samples with TaqMan qPCR than with nested PCR over the two years $(t=-3.82, d f=19, P<0.01)$. There were five times more positive samples with the TaqMan qPCR assay compared with nested PCR in 2014 (45 and 9, respectively) (Table 1), but the number of positives samples with the two methods was almost the same in 2015, i.e., 24 and 23, respectively (Table 1). For all samples tested in Ct range 20 to 39, there was no correlation between TaqMan qPCR
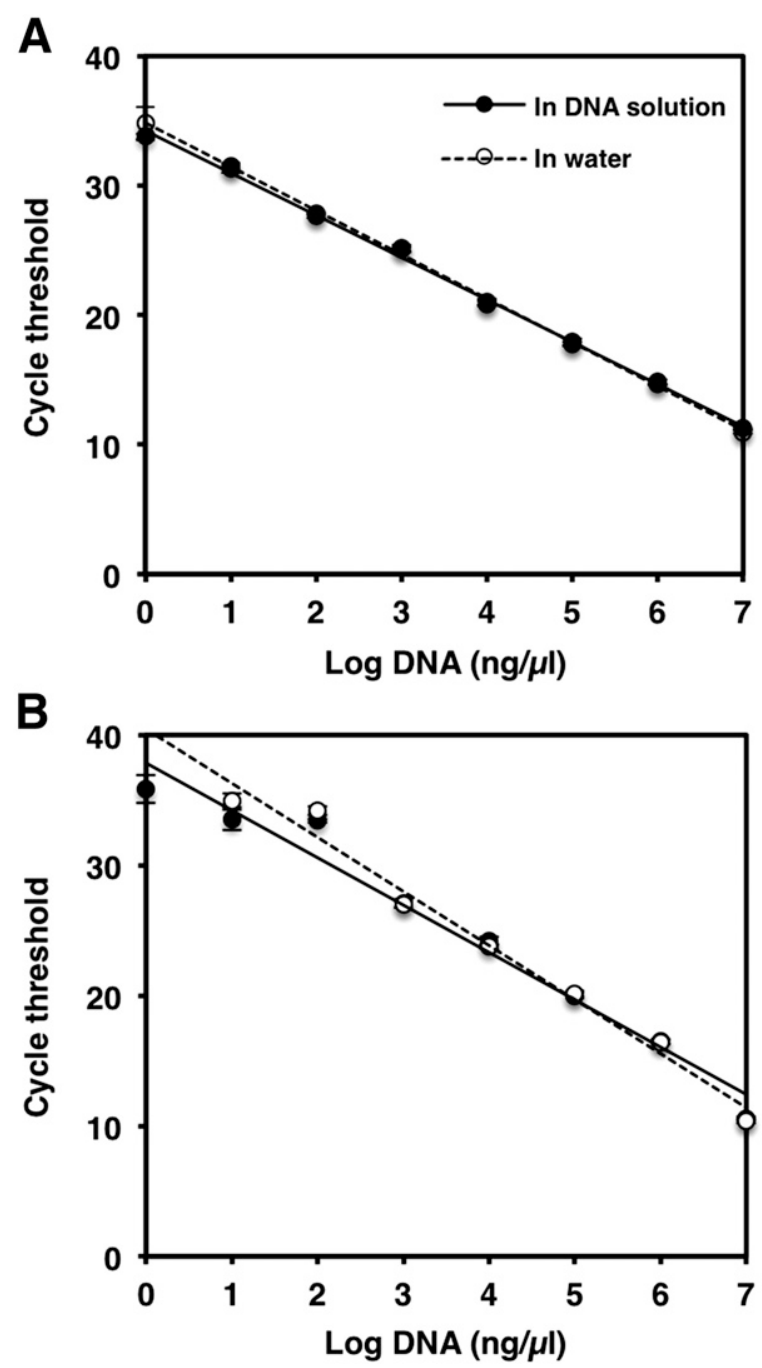

Fig. 2. Standard curves for quantitative polymerase chain reaction ( $q P C R)$ assays. Phytoplasma gene targets were cloned into a plasmid vector and plasmid copy number per microliter was calculated and a 10 -fold dilution series was created. The most diluted sample for TaqMan and SYBR green qPCR contained four and eight plasmid copies, respectively. All samples were run in triplicate and error bars represent standard deviation. A, TaqMan qPCR assay had a primer efficiency of $103.5 \%$ and $\mathbf{B}$, the SYBR green qPCR assay had a primer efficiency of $90.3 \%$. 
and nested PCR in the number of positive samples obtained $(r=-0.44$, $P=0.05$ ). For $\mathrm{Ct}$ values 20 to 30 , there was a significant correlation between TaqMan qPCR and nested PCR in the number of positive samples $(r=0.65, P<0.05)$, but no correlation for $\mathrm{Ct}$ range 31 to 39 between the two assays $(r=0.14, P=0.72)$ (Fig. 4$)$. After testing a subset $(12 \%)$ of the TaqMan positive samples with SYBR green qPCR, 93.8\% were positive with both methods in 2014 and $100 \%$ in 2015 . There was a positive correlation between the $\mathrm{Ct}$ values of the 185 samples that were tested with both qPCR assays $(r=0.85, P<0.01)$ (Fig. 5).

Phytoplasma prevalence. Generally, the tested methodologies concurred in finding that AYp prevalence increased during the 2014 growing season and decreased in 2015 (Fig. 6). In 2014, there was a significant positive relationship for prevalence during the growing season with TaqMan qPCR $\left(R^{2}=0.12, P<0.05\right)$, but this relationship was not significant with nested PCR $\left(R^{2}=0.0009\right.$,

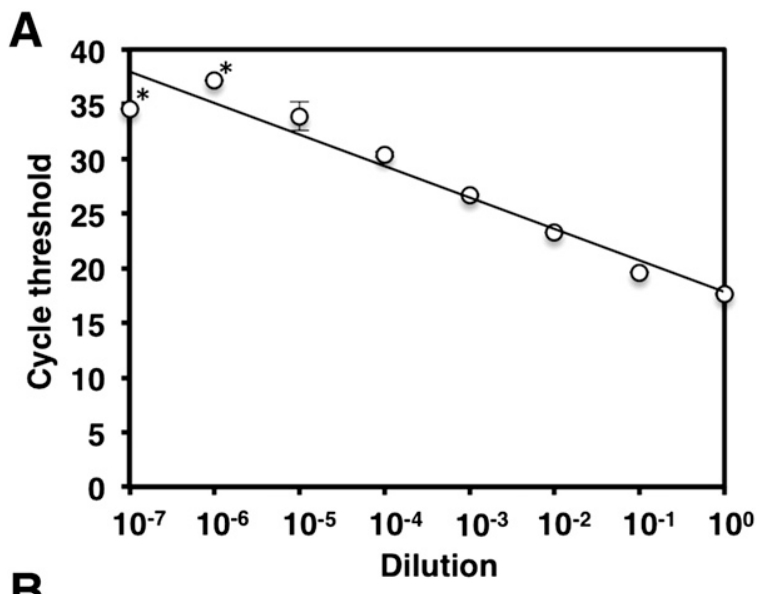

B
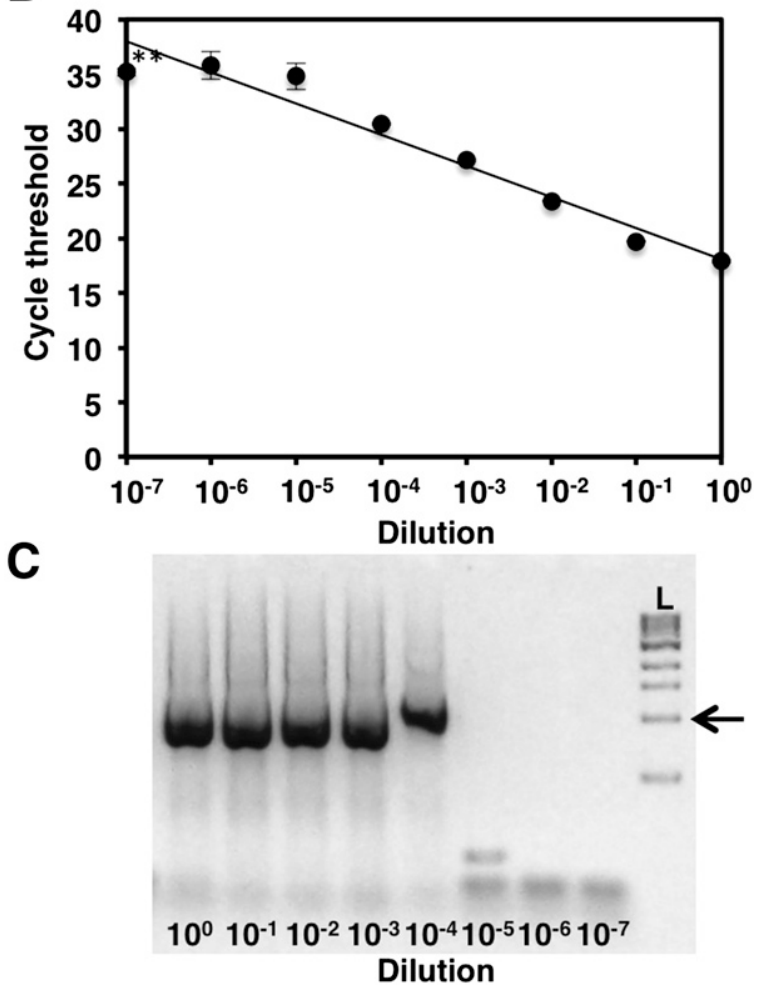

Fig. 3. Comparison of the sensitivities of three diagnostic assays. A dilution series $\left(10^{-1}\right.$ to $10^{-7}$ ) of a sample that was placed by restriction fragment length polymorphism in the 16Srl-B phytoplasma group was tested using all three polymearse chain reaction (PCR) assays. A, Dilution series with TaqMan quantitative (q)PCR assay, each dilution was run in triplicates. An asterisk (*) indicates that only one of the three replicates amplified. B, Dilution series with SYBR green QPCR assay, each dilution was run in triplicates. Two asterisks ${ }^{* *}$ ) indicate that only two of the three replicates amplified. C, Nested PCR products run on a $1 \%$ agarose gel prestained with GelRed and run at $90 \mathrm{~V}$ for $50 \mathrm{~min}$. Well L contains a 1-kb ladder containing $62.5 \mathrm{ng}$ of DNA. The arrow indicates the location of a 1,000-bp product.
$P=0.85$ ) (Fig. 6A). In 2015, there was a significant negative relationship between the number of samples and date during the growing season with TaqMan qPCR $\left(R^{2}=-0.11, P<0.05\right)$, but this was not significant with nested PCR $\left(\mathrm{R}^{2}=-0.02, P=0.31\right)$ (Fig. 6B).

\section{Discussion}

Numerous PCR-based assays have been developed over the last 20 years for detecting phytoplasmas (Nejat and Vadamalai 2013), yet information on the accuracy and efficiency of these published methods for the diagnostics of field-collected insect samples has been lacking. The development of a fast, sensitive, and accurate high-throughput method for testing large numbers of leafhoppers would allow for improved monitoring of AYp in agricultural production. Detecting the presence of the pathogen in the leafhopper and determining the proportion of the population carrying AYp is essential to refine current decision-making tools for managing the disease vector with foliar insecticide sprays. We tested over 3,000 leafhoppers from two growing seasons to fill this knowledge gap. By comparing multiple techniques, our study identified two rapid qPCR assays that are currently available to detect phytoplasma in field-collected aster leafhoppers. However, additional research needs to be performed before using these primers on a large scale for AYp detection in leafhoppers.

One of our significant findings was that nested PCR yielded uncertain results, where multiple positive samples could not be replicated with retesting. Since these samples gave faint bands initially, this could have been caused by cross contamination due to the repeated handling of the samples after the first PCR amplification. Alternatively, these samples could have contained phytoplasma at extremely low levels that were difficult to visualize on an agarose gel, leading to false negative results. This is a likely explanation, since $85.7 \%$ of the positive samples that could not be replicated with nested PCR

Table 3. Comparison of time to complete three polymerase chain reaction (PCR) assays to detect aster yellows phytoplasma in aster leafhoppers

\begin{tabular}{lccc}
\hline & $\begin{array}{c}\text { Nested } \\
\text { PCR }\end{array}$ & $\begin{array}{c}\text { TaqMan quantitative } \\
\text { (q)PCR }\end{array}$ & $\begin{array}{c}\text { SYBR } \\
\text { green } \\
\text { qPCR }\end{array}$ \\
\hline DNA extraction (hours) & 3 & 3 & 3 \\
Sample preparation (hours) & 2 & 1 & 1 \\
In machine (hours) & 7.5 & 1.5 & 2 \\
Gel electrophoresis (hours) & 1.5 & N/A & N/A \\
Total & 14 & 5.5 & 6 \\
\hline
\end{tabular}

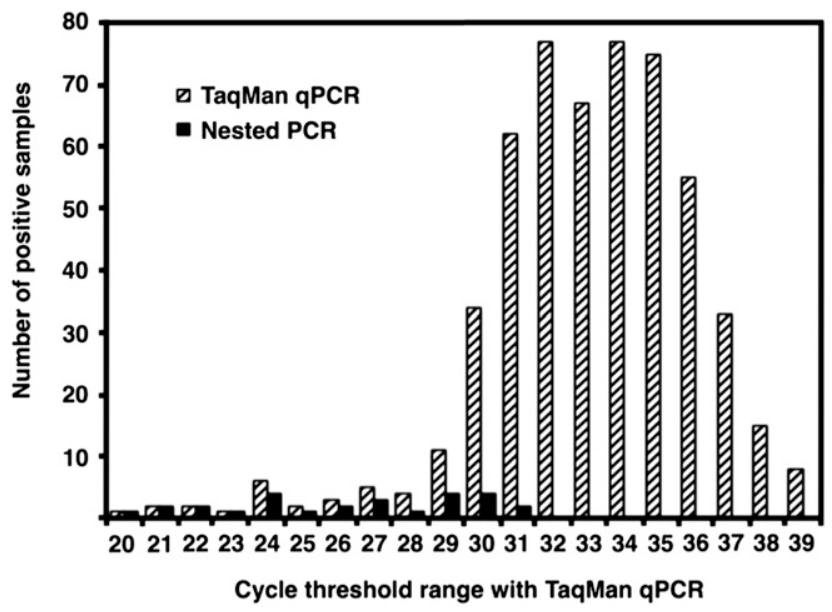

Fig. 4. A comparison of the number of nested polymerase chain reaction (PCR) and TaqMan quantitative (q)PCR positive samples at each cycle threshold (Ct). For $\mathrm{Ct}$ values 20 to 30 , there is a significant correlation between TagMan QPCR and nested PCR in the number of positive samples $(r=0.65, P<0.01)$. For $\mathrm{Ct}$ values 31 to 39 , there is no correlation between the number of positive samples generated with the two methods $(r=0.14, P=0.72)$. A Ct value of 31 was used as a cutoff value for determining positive samples. 
amplified with TaqMan qPCR at higher $\mathrm{Ct}$ values $(>31)$. In a previous study, $10 \%$ of samples were false negatives with a nested PCR assay for AYp in the leafhopper Macrosteles quadripunctulatus (Bertin et al. 2004). In the current study, $64.7 \%$ of samples positive with TaqMan qPCR $(\mathrm{Ct}<31)$ were negative with nested PCR. In addition, the concentration of DNA was not standardized before running all PCR assays due to the large sample size. It is possible that, for some samples, there was not enough DNA to show amplification with nested PCR. Therefore, especially under time constraints, a qPCR assay may be a more practical option because it can typically detect lower levels of phytoplasma.

A small number of nested PCR positive samples (4 of 37) were considered false positives because the RFLP patterns did not match published phytoplasma profiles. This is in agreement with other studies in which universal primers occasionally amplified nontarget bacterial species (Harrison et al. 2002; Lee et al. 2002). While the RFLP analysis is necessary to verify positive samples, it increases the time for accurate phytoplasma detection. RFLP analysis revealed that the phytoplasmas in our samples belonged to the AYp subgroups A and $\mathrm{B}$, and we found no evidence of other phytoplasma outside the AYp group. Both AYp subgroups A and B have been previously detected in North America (Lee et al. 1998; Wally et al. 2008).

TaqMan qPCR has been shown to increase specificity (Holland et al. 1991) and is likely able to detect lower levels of phytoplasma compared with conventional PCR without PCR inhibition (Hren et al. 2007) (Fig. 3). In addition, the conditions of qPCR may be more favorable for detecting AYp at low concentrations compared with the nested PCR. Given that there were more qPCR-only positives at higher $\mathrm{Ct}$ values and there was a higher limit of detection for qPCR as shown in Figure 3, this is a possibility. In addition, 97.4\% (113 of 116) of the samples positive with TaqMan qPCR had a Ct of less than 32 with SYBR green qPCR, showing that the qPCR assays are targeting the same organism. Due to the large number of samples that were positive with TaqMan qPCR but negative with nested PCR, the TaqMan assay may have been amplifying other nontarget bacterial species in the leafhoppers; this is a likely explanation, since the TaqMan qPCR primers we used are known to amplify nonphytoplasma bacteria at high $\mathrm{Ct}$ values (Christensen et al. 2004). We detected at least eight false negatives with TaqMan qPCR, where nested PCR samples that matched published AYp RFLP profiles were not positive using TaqMan qPCR. Of these eight samples, four did not show any amplification with either qPCR assay. In addition, the greater number of positives with TaqMan qPCR compared with the traditional nested PCR assay shows that there are likely specificity issues. Thus, the two qPCR assays, like the nested PCR assay, are not completely reliable for detecting AYp in leafhoppers. Future research will identify the

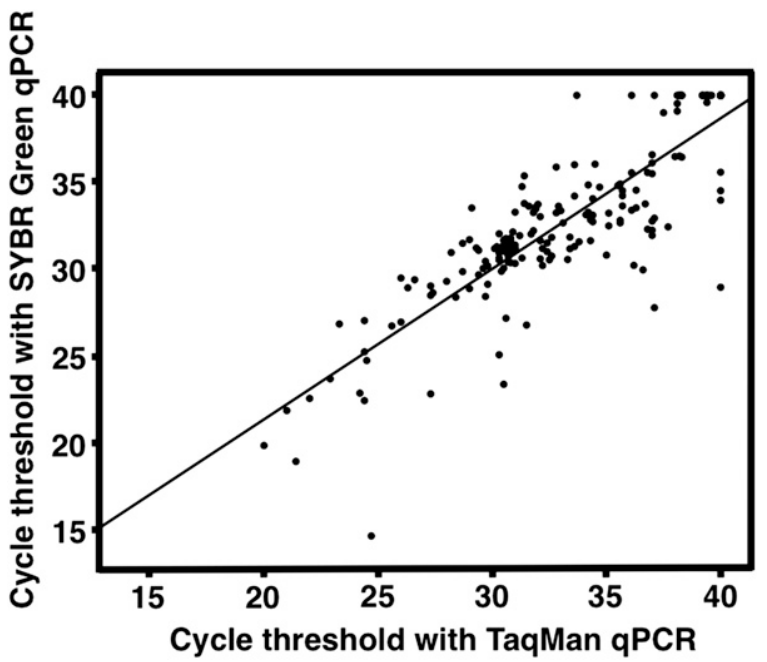

Fig. 5. Relationship between the cycle threshold (Ct) values using TaqMan and SYBR green quantitative polymerase chain reaction (qPCR) assay. There was a significant correlation between the $\mathrm{Ct}$ values of 185 samples tested with both qPCR assays $(r=$ $0.85, P<0.01)$. Undetermined values were set to $\mathrm{Ct} 40$. specific number of false positives obtained with both qPCR assays, which will enable us to determine the clinical sensitivity and diagnostic specificity of these assays. This will ensure that growers receive accurate information about the potential risk of AYp infection.

We expected to see an increase over time in the proportion of leafhoppers carrying AYp, since disease incidence tends to increase in plants over the growing season. This was the case in 2014, but the pattern reversed in 2015, when a smaller proportion of the leafhoppers were carrying the disease later in the season compared with May or June. Leafhoppers acquire phytoplasmas along their migration route from the southern United States (Chapman 1973), thus, it is likely that, in some years, the populations that arrive in Michigan early in the season carry a high proportion of AYp. Similar results were found in Canada, where the proportion of AYp-infected leafhoppers decreased over the season in some years (Wally et al. 2004).

A question that remains is whether the quantity of AYp in a leafhopper could be used to determine the likelihood of plant infection in the field. Leafhoppers that are PCR-positive for phytoplasma are not necessarily infectious due to the 20- to 25-day-long vector latent period at midsummer temperatures (Murral et al. 1996). The variability of obtained $\mathrm{Ct}$ values and low positive sample sizes pose some limitations on how this information can be interpreted for decisionmaking. However, phytoplasma presence in the leafhoppers still gives

A

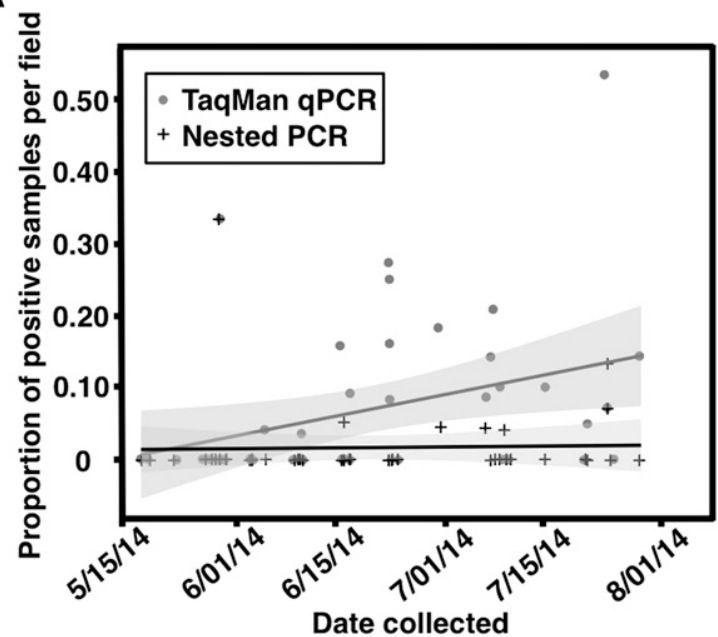

B

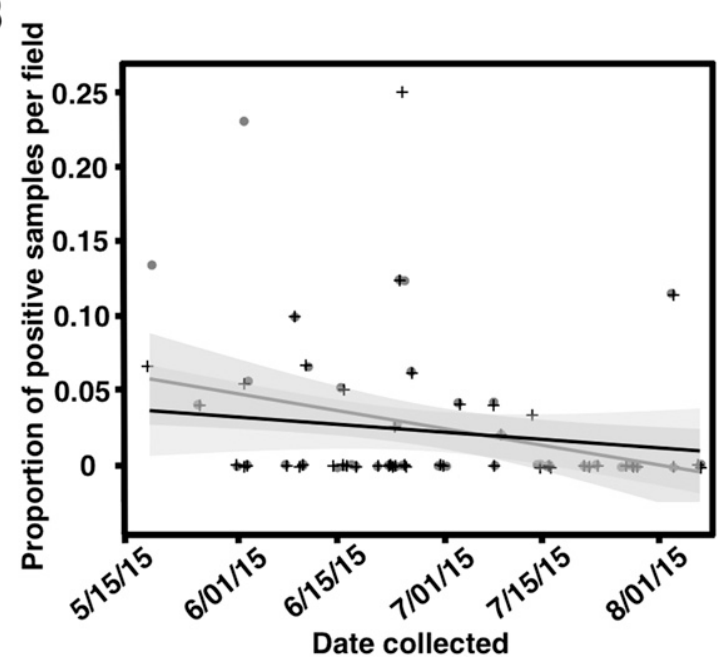

Fig. 6. Presence of phytoplasma in field-collected leafhoppers for two consecutive growing seasons. A, Proportion of samples positive per field and collection day in the 2014 growing season for TaqMan quantitative polymerase chain reaction (qPCR) $\left(R^{2}=0.12, P<0.05\right)$ and nested PCR $\left(R^{2}=0.0009, P=0.85\right)$. B, Proportion of samples positive per field and collection day in the 2015 growing season for TaqMan qPCR $\left(R^{2}=-0.11, P<0.05\right)$ and nested PCR $\left(R^{2}=-0.02, P=0.31\right)$. Shaded gray regions indicate the $95 \%$ confidence interval of the mean. 
diagnosticians information about the likelihood of phytoplasma infection of crops (Goodwin et al. 1999; Wally et al. 2004). We also need to learn more about which leafhopper species are involved in AYp transmission in our system. In the current study, only aster leafhoppers were tested and, although this species is the main vector in vegetable crops in the region (Hoy et al. 1992), there may be other phloem-feeding insects that may also contribute to aster yellows infection. For example, the potato leafhopper Empoasca fabae is known to inhabit vegetable fields, but we have no information on its contribution to AYp infection. Therefore, testing additional phloem-feeding insects may contribute to the understanding about phytoplasma prevalence in agricultural systems by pointing to another potential insect vector of AYp. If other insects were to test AYp-positive, transmission assays in the laboratory could show if the insects were able to maintain and transmit the pathogen.

In summary, both qPCR assays allowed for quick results, with samples processed over two times faster with the qPCR assays than with the nested PCR assay. Phytoplasma prevalence can, therefore, be obtained within $24 \mathrm{~h}$ of leafhopper collection, increasing sample turnaround time with qPCR. Although the qPCR assays used in this study were shown to be slightly more sensitive than nested PCR, there are likely specificity issues with these assays, due to the presence of false-positive results. This study shows that these assays are not completely reliable for diagnosing AYp prevalence in leafhoppers in the field and indicates that a more reliable qPCR method with a known sensitivity and specificity needs to be developed, to be able to quickly and accurately detect AYp in leafhoppers. This is essential in preventing outbreaks of AYp in susceptible agricultural crops in the future.

\section{Acknowledgments}

Support for this study was provided by Michigan State University Project GREEEN (Generating Research and Extension to meet Economic and Environmental Needs). We thank L. Komondy for her help testing 2015 leafhopper samples. We also thank B. Werling, B. Phillips, M. Crossley, and J. Kansman for collecting the leafhoppers used in this study.

\section{Literature Cited}

Aljanabi, S. M., and Martinez, I. 1997. Universal and rapid salt-extraction of high quality genomic DNA for PCR-based techniques. Nucleic Acids Res. 25:4692-4693.

Bertin, S., Palermo, S., Marzachi, C., and Bosco, D. 2004. A comparison of molecular diagnostic procedures for the detection of aster yellows phytoplasmas (16Sr-I) in leafhopper vectors. Phytoparasitica 32:141-145.

Bohuski, E., Lorch, J. M., Griffin, K. M., and Blehert, D. S. 2015. TaqMan realtime polymerase chain reaction for detection of Ophidiomyces ophiodiicola, the fungus associated with snake fungal disease. BMC Vet. Res. 11:95.

Chapman, R.K. 1973. Integrated control of aster yellows. Pages 71-92 in: Proceedings North Central Branch of the Entomological Society of America Vol. 28. CAB International, Wallingford, U.K.

Christensen, N. M., Nicolaisen, M., and Hansen, M. 2004. Distribution of phytoplasmas in infected plants as revealed by real-time PCR and bioimaging. Mol. Plant-Microbe Interact. 17:1175-1184.

Christensen, N. M., Axelsen, K. B., Nicolaisen, M., and Schulz, A. 2005. Phytoplasmas and their interactions with hosts. Trends Plant Sci. 10: 526-535.

Crosslin, J. M., Vandemark, G. J., and Munyaneza, J. E. 2006. Development of a real-time, quantitative PCR for detection of the Columbia basin potato purple top phytoplasma in plants and beet leafhoppers. Plant Dis. 90:663-667.

Delahaut, K. A. 1997. Aster Yellows. Fact sheet. No. A3679. University of WisconsinExtension. Cooperative Extension Publishing, Madison, WI. Published online.

Franova, J. 2011. Difficulties with conventional phytoplasma diagnostic using PCR/RFLP analyses. Bull. Insectology 64 (Supplement):S287-S288.

Frost, K. E., Willis, D. K., and Groves, R. L. 2011. Detection and variability of aster yellows phytoplasma titer in its insect vector, Macrosteles quadrilineatus (Hemiptera: Cicadellidae). J. Econ. Entomol. 104:1800-1815.

Frost, K. E., Esker, P. D., Van Haren, R., Kotolski, L., and Groves, R. L. 2013. Seasonal patterns of aster leafhopper (Hemiptera: Cicadellidae) abundance and aster yellows phytoplasma infectivity in Wisconsin carrot fields. Environ. Entomol. 42:491-502.

Galetto, L., and Marzachi, C. 2009. Pages 1-18 in: Real-time PCR diagnosis and quantification of phytoplasmas. Phytoplasmas: Genomes, Plant Hosts, and Vectors. Weintraub, P. G., and Jones, P., eds. CABI Publishing, Wallingford, U.K.
Goodwin, P. H., Mahuku, G. S., Liu, H., and Xue, B. G. 1999. Monitoring phytoplasma in populations of aster leafhoppers from lettuce fields using the polymerase chain reaction. Crop Prot. 18:91-99.

Gundersen, D. E., and Lee, I.-M. 1996. Ultrasensitive detection of phytoplasmas by nested-PCR assays using two universal primer pairs. Phytopathol. Mediterr. 35:114-151

Harrison, N. A., Womack, M., and Carpio, M. L. 2002. Detection and characterization of a lethal yellowing (16SrIV) group phytoplasma in Canary Island palms affected by lethal decline in Texas. Plant Dis. 86:676-681.

Holland, P. M., Abramson, R. D., Watson, R., and Gelfand, D. H. 1991. Detection of specific polymerase chain reaction product by utilizing the $5^{\prime}-3^{\prime}$ exonuclease activity of Thermus aquaticus DNA polymerase. Proc. Natl. Acad. Sci. USA 88:7276-7280.

Hollingsworth, C. R., Atkinson, L. M., Samac, D. A., Larsen, J. E., Motteberg, C. D., Abrahamson, M. D., Glogoza, P., and MacRae, I. V. 2008. Region and field level distributions of aster yellows phytoplasma in small grain crops. Plant Dis. 92:623-630.

Hoy, C. W., Heady, S. E., and Koch, T. A. 1992. Species composition, phenology, and possible origins of leafhoppers (Cicadellidae) in Ohio vegetable crops. J. Econ. Entomol. 85:2336-43.

Hren, M., Boben, J., Rotter, A., Kralj, P., Gruden, K., and Ravnikar, M. 2007. Real-time PCR detection systems for Flavescence doree and Bois noir phytoplasmas in grapevine: Comparison with conventional PCR detection and application in diagnostics. Plant Pathol. 56:785-796.

Jawhari, M., Abrahamian, P., Sater, A. A., Sobh, H., Tawidian, P., and Abou-Jawdah, Y. 2015. Specific PCR and real-time PCR assays for detection and quantification of 'Candidatus Phytoplasma phoenicium.'. Mol. Cell. Probes 29:63-70.

Lee, I.-M., Hammond, R. W., Davis, R. E., and Gundersen, D. E. 1993. Universal amplification and analysis of pathogen 16S rDNA for classification and identification of mycoplasmalike organisms. Phytopathology 83:834-842.

Lee, I.-M., Gundersen-Rindal, D. E., Davis, R. E., and Bartoszyk, I. M. 1998. Revised classification scheme of phytoplasmas based on RFLP analyses of 16S rRNA and ribosomal protein gene sequences. Int. J. Syst. Bacteriol. 48:1153-1169.

Lee, I.-M., Davis, R. E., and Gundersen-Rindal, D. E. 2000. Phytoplasma: Phytopathogenic mollicutes. Annu. Rev. Microbiol. 54:221-255.

Lee, M. E., Grau, C. R., Lukaesko, L. A., and Lee, I.-M. 2002. Identification of aster yellows phytoplasmas in soybean in Wisconsin based on RFLP analysis of PCR-amplified products (16S rDNAs). Can. J. Plant Pathol. 24:125-130.

Lee, I. M., Martini, M., Bottner, K. D., Dane, R. A., Black, M. C., and Troxclair, N. 2003. Ecological implications from a molecular analysis of phytoplasmas involved in an aster yellows epidemic in various crops in Texas. Phytopathology 93:1368-1377.

Mahr, S. E. R., Wyman, J. A., and Chapman, R. K. 1993. Variability in aster yellows infectivity of local populations of the aster leafhopper (Homoptera: Cicadellidae) in Wisconsin. Hortic. Entomol. 86:1522-1526.

Murral, D. J., Nault, L. R., Hoy, C. W., Madden, L. V., and Miller, S. A. 1996. Effects of temperature and vector age on transmission of two Ohio strains of aster yellows phytoplasma by the aster leafhopper (Homoptera: Cicadellidae) J. Econ. Entomol. 89:1223-1232.

Nejat, N., and Vadamalai, G. 2013. Diagnostic techniques for detection of phytoplasma diseases: Past and present. J. Plant Dis. Prot. 120:16-25.

Schneider, B., and Seemuller, E. 1994. Presence of two sets of ribosomal genes in phytopathogenic mollicutes. Appl. Environ. Microbiol. 60:3409-3412.

Schneider, B., Ahrens, U., Kirkpatrick, B. C., and Seemuller, E. 1993. Classification of plant-pathogenic mycoplasma-like organisms using restriction-site analysis of PCR-amplified 16S rDNA. J. Gen. Microbiol. 139:519-527.

Schneider, B., Seemüller, E., Smart, C. D., and Kirkpatrick, B. C. 1995:Pages 369-380 in: Phylogenetic classification of plant pathogenic mycoplasmalike organisms or phytoplasmas. Molecular and Diagnostic Procedures in Mycoplasmology. Razin, I. R., and Tully, J. G., eds. Academic Press, San Diego.

Torres, E., Bertolini, E., Cambra, M., Monton, C., and Martin, M. P. 2005. Real time PCR for simultaneous and quantitative detection of quarantine phytoplasmas from apple proliferation (16SrX) group. Mol. Cell. Probes 19:334-340.

Wally, O., Daayf, F., Khadhair, A. H., Adam, L., Elliott, B., Shinners-Carnelley, T., Iranpour, M., Northover, P., and Keyworth, S. 2004. Incidence and molecular detection of yellows-type disease in carrots, associated with leafhoppers in southern Manitoba, Canada. Can. J. Plant Pathol. 26:498-505.

Wally, O., El Hadrami, A., Khadhair, A. H., Adam, L. R., Shinners-Carnelley, T., Elliot, B., and Daayf, F. 2008. DNA sequencing reveals false positives during the detection of aster yellows phytoplasma in leafhoppers. Sci. Hortic. (Amsterdam) 116:130-137.

Wei, W., Davis, R. E., Lee, I.-M., and Zhao, Y. 2007. Computer-simulated RFLP analysis of $16 \mathrm{~S}$ rRNA genes: Identification of ten new phytoplasma groups. Int J. Syst. Evol. Microbiol. 57:1855-1867.

Weintraub, P. G., and Beanland, L. 2006. Insect vectors of phytoplasmas. Annu. Rev. Entomol. 51:91-111. 